\title{
„Jeśli rzeczy mają potoczyć się dalej..." - potencjalność i entropia we wczesnej prozie Magdaleny Tulli
}

\author{
Bogumiła Kaniewska
}

ORCID: 0000-0001-5448-2752

\section{Krzysztof Skibski}

ORCID: 0000-0001-7548-1687

Jedną z konsekwencji akomodowania elementów języka, włączania ich w ciągi składniowe, a później tekstowe, jest implikacja ciągłości i domniemanie wyróżnienia ${ }^{1}$. Tekst prozatorski, zwłaszcza powieść, eksponując rolę osoby opowiadającej, zapowiada rekonstrukcję punktu widzenia, być może kilku naraz, ale jednak z odesłaniem do jakiejś (zdeterminowanej wyborem sposobu narracji) konstrukcji świata. Czy jest on de facto przedstawiony, czy raczej sugerowany, wpisany w nieusuwalne napięcie między wyobrażeniem czytelniczym a typowym odniesieniem zleksykalizowanych elementów języka - to już sprawa nieco dalsza. Dość stwierdzić, że aranżowanie sytuacji komunikacyjnej w następujących po sobie wypowiedzeniach spójnego tekstu ma potencjał metafory, czyli w jakiejś mierze z pewnością przywołuje problem referencji ${ }^{2}$. W myśli literaturoznawczej zagadnienie to podlegało refleksji na poziomie fikcji: konkretyzacja w ujęciu Romana Ingardena czy też pojęcie FPO (fikcyjnego pola odniesienia) stworzone przez Jerzego Ziomka wskazywały z jednej strony na potencjalność tekstu (a więc

\footnotetext{
${ }^{1}$ Por. Zygmunt Saloni, Marek Świdziński, Składnia współczesnego języka polskiego (Warszawa: Wydawnictwo Naukowe PWN, 2007), 108-122.

${ }^{2}$ Zob. Donald Davidson, Inquires into Truth and Interpretation (Oxford University Press, 1991).
} 
jego zdolność do wypromieniowania wokół siebie ontologicznej otoczki własnego bytu, zakorzenienia w fikcyjnym świecie), z drugiej ukazywały jego związki ze światem rzeczywistym, a więc: niewystarczalność, niekompletność i otwartość rzeczywistości wykreowanej ze słów³.

Rozpoczęty w ten sposób artykuł ma na celu podjęcie kwestii składni literackiej w prozie Magdaleny Tulli. Oryginalność języka, którym pisarka się posługuje, była już wielokrotnie wskazywana ${ }^{4}$, jednak chcemy zaproponować przyjrzenie się kilku zjawiskom szczegółowym, wymagającym spojrzenia pogranicznego - językoznawczo-literaturoznawczego ${ }^{5}$. Nie jest to pomysł nowy: już w myśleniu Romana Jakobsona pojawiał się postulat, by poetyka stanowiła gałąź literaturoznawstwa - przekładając ten, dobrze znany, teoretyczny postulat na praktykę, odpowiadamy na pytanie, jak mówi forma, czy precyzyjnie: jak autor buduje sensy, wykorzystując możliwości językowego tworzywa. Wśród zjawisk obserwowanych w prozie Tulli warto na początku wymienić akomodację stylistyczną ${ }^{6}$, elementy metaskładni czy projekt składni aranżującej. Wszystkie one bowiem zapowiadają położenie akcentu na gramatykę literacką, a dopiero w następnym etapie - na propozycje interpretacyjne. Te ostatnie zresztą mają już swoje utrwalone w literaturze przedmiotu bogactwo i różnorodność. Proponowana przez nas perspektywa będzie zatem służyła odczytaniom następnym i kolejnym analizom tego ciekawego, enigmatycznego pisarstwa.

${ }^{3}$ Por. Roman Ingarden, „Z teorii dzieła literackiego”, w: Problemy teorii literatury. S. 1, red. H. Markiewicz (Wrocław: Ossolineum, 1987); Jerzy Ziomek, Fikcyjne pole odniesienia a problem quasi-sądów, w: Wypowiedź literacka a wypowiedź filozoficzna, red. M. Głowiński, J. Sławiński (Wrocław: Ossolineum, 1982).

${ }^{4}$ Od razu trzeba podkreślić, że kwestie związane ze światem (nie)przedstawianym, a więc i złożoną referencją analizowaną w kontekście wczesnych utworów Magdaleny Tulli omówiła Agnieszka Izdebska, rekonstruując dyskusję nad problemem metaliterackości czy potencjalności interpretacyjnej („Proza Magdaleny Tulli - w kręgu wieloznacznej referencji”, w: Inna literatura? Dwudziestolecie 1989-2009, red. Z. Andres, J. Pasterski, t. 1 [Rzeszów: Wydawnictwo Uniwersytetu Rzeszowskiego, 2010], 303-322). Autorka przytacza również obszerne wypowiedzi badaczy reagujących na kolejne prozy Tulli (m.in. P. Czaplińskiego, T. Kunza czy K. Uniłowskiego). Sposoby budowania opowieści rozpatruje także Elżbieta Dutka (również obszernie rekonstruując stan badań na ten temat) w pracy „Historyjki czy historie? Parabole czy alegorie?: o prozie Magdaleny Tulli”, w: Skład osobowy: szkice o prozaikach wspótczesnych. Cz. 1, red. A. Nęcka, D. Nowacki, J. Pasterska (Katowice: Wydawnictwo Uniwersytetu Śląskiego, 2014), 525-550. Jednakowoż należy też wspomnieć o wybitnych komentatorach twórczości autorki Skazy, którzy wskazywali w swoich tekstach kwestie osobliwości języka, metaforycznego potencjału czy nieciągłości frazy - tu zaś przede wszystkim prace: Przemysława Czaplińskiego - „Wobec literackości (2): Metafikcja i nieepicki model prozy”, w tegoż: Ślady przełomu. O prozie polskiej 1976-1996 (Kraków: Wydawnictwo Literackie, 1997), Tomasza Mizerkiewicza - „Dezautomatyzacja skojarzeń kulturowych i wolność literatury - Sny i kamienie Magdaleny Tulli”, w tegoż: Stylizacje mityczne w prozie polskiej po 1968 roku (Poznań: Wydawnictwo „Poznańskie Studia Polonistyczne”, 2001), Arkadiusza Morawca - „Sny i kamienie Magdaleny Tulli - płaszczyzny odczytan”, w: Literatura polska 1990-2000, red. T. Cieślak, K. Pietrych, t. 2 (Kraków: Zielona Sowa, 2002), Ewy Wiegandt - „Postmodernistyczne alegorie Magdaleny Tulli”, w: Nowe dwudziestolecie. Szkice o wartościach i poetykach prozy i poezji lat 1989-2009, red. P. Śliwiński (Poznań: Wydawnictwo WBPiCAK, 2011), Marka Zaleskiego - „Za plecami narratora. Rozmowa z Magdaleną Tulli”, Res Publica Nowa 5-6 (1999) czy Andrzeja Zieniewicza - „Przedmiot (w) opowieści. Relacja jako stwarzanie wydarzeń w prozie współczesnej (na przykładzie powieści Magdaleny Tulli)”, w: Narracje po końcu (wielkich) narracji. Kolekcje, obiekty, symulakra..., red. H. Gosk, A. Zieniewicz (Warszawa: Dom Wydawniczy Elipsa, 2007). Prozy Tulli były też - z racji swojej oryginalności - obficie recenzowane (zob. http:// www.ppibl.ibl.waw.pl/mediawiki/index.php?title=Magdalena_TULLI, dostęp 30.10.2021).

${ }^{5}$ W tej perspektywie rozpatrywała prozę Tulli Ewa Sławkowa, analizując przede wszystkim problem nominalizacji w szerszym kontekście refleksji semantycznej. Badaczka - w odniesieniu do książki Sny i kamienie - pisze: „W swojej wizji świata jako historii miasta Tulli oddala się zatem od ujęcia problematyki znaczenia z perspektywy prawdziwościowej semantyki referencjalnej (od modelu obiektywistycznego), skłaniając się wyraźnie ku nowszym rozwiązaniom w teorii znaczenia, preferującym model subiektywistyczny. Snom i kamieniom patronuje niewątpliwie kulturowa teoria języka, bliska antropologiczno-kognitywistycznym jego ujęciom. Pojawia się sposób myślenia o języku jako o fenomenie powiązanym ze zjawiskami kultury: z jednej strony będącym częścią zachowań społecznych i służącym ludzkiemu porozumiewaniu, z drugiej zaś - stanowiącym narzędzie mentalnego ujmowania świata przez człowieka („Sny i kamienie - traktat o języku: Magdaleny Tulli ćwiczenia z semantyki”, w tejże: Tekst literacki w kręgu językoznawstwa, t. 1 [Katowice: Wydawnictwo Gnome, 2012], 15-38).

${ }^{6}$ Zob. Teresa Skubalanka, Podstawy analizy stylistycznej. Rozważania o metodzie, Lublin 2001. 
Z uwagi na cechy swoiste utworów pisarki będziemy się odnosić do pierwszych czterech powieści wydanych w latach 1995-20067. Wychodzimy bowiem z założenia, że można te teksty analizować w odniesieniu do opisanych przez nas w tym szkicu zjawisk językowych, a ponadto wybór taki koresponduje z refleksją literaturoznawczą na temat specyfiki dotychczasowej twórczości Tulli. Te cztery teksty stanowią zapowiedź późniejszego rozwoju pisarki, zarazem są one mniej wyeksploatowane interpretacyjnie i tym samym tworzą ciekawy i inspirujący kontekst oświetlający całość tej twórczości.

Czytelniczy niepokój po lekturze wcześniejszych powieści Tulli, ich interpretacyjna zagadkowość i wieloznaczność mogą wynikać z kilku czynników. Przede wszystkim z zabiegów imitacyjnych - w grę wchodzi tu zarówno problematyka początku (opowieści, miasta, zdarzenia), dramaturgia i przebieg zdarzeń (ich wzajemne relacje, zależności, konsekwencje), wreszcie analogia. Ta ostatnia jest bodaj kluczowa. W skondensowanych prozach bowiem odnajdujemy reminiscencje polskiej historii (Sny i kamienie, Skaza), standardów obyczajowych (W czerwieni, Tryby) czy antropologicznych pytań elementarnych (wszystkie cztery powieści). Co więcej, we wszystkich tekstach, choć w różnym natężeniu, słychać literackie echa: Schulza, Kafki, Calvino i innych. Niepokój nie wynika jednak z samego przywoływania, lecz z efektu opowieści. Dynamika czytelniczej partycypacji w tych prozach obejmuje również radzenie sobie z osobliwym nadmiarem - nadmiarem znaczeń i nadmiarem znaków. Nie jest on spowodowany słowną nadreprezentacją tekstu, lecz raczej sposobem konstruowania językowego obrazu sceny. Właśnie tak, ponieważ ewokacja językowego obrazu świata jest w tym przypadku dyspozycją odbiorcy. Scena ma określone właściwości, które wynikają - naszym zdaniem - z organizacji języka wypowiedzi, a więc - ze składni literackiej.

\section{Opowieść entropiczna - jednoczesność i następstwo}

Opowieść koncentrująca się na zdarzeniu głównym rodzi pokusę kondensacji - jej literackim przykładem jest forma klasycznej noweli, gatunku doskonale zdyscyplinowanego, w którym wszystko ogniskuje się wokół tak zwanego sokoła noweli. Dotyczy to także języka - w języku niepotocznym oznacza to często destylowanie przekazu do niezbędnego (i klarownego informacyjnie) minimum, co idealizacyjnie tworzy wrażenie, że przyczynowo-skutkowy porządek jest naturalnym zjawiskiem $\mathrm{w}$ świecie. W potocznym zaś języku pojawiają się spontaniczne sygnały wieloczynnikowości - obfitość zaimków, retrospektywy, zmiany leksykalne w trakcie opowieści. Pozorne zerwania ciągłości w opowiadaniu mają jednak zwykle właściwości spajające. Wszystkie bowiem elementy spontanicznego uzupełnienia świadczą o nieoczywistości przebiegu opowiadanego zdarzenia, o przyczynach cząstkowych, włączających się w trakcie zjawiska, a także - o nielinearności, która nie daje się bez uszczerbku transponować na ciągłość tekstu. Tak jest w komunikacji codziennej. Pamiętając o tym rozróżnieniu, spójrzmy na taki fragment prozy Tulli:

\footnotetext{
${ }^{7}$ Są to zatem teksty: Sny i kamienie (1995), W czerwieni (1998), Tryby (2003) i Skaza (2006). Cytaty z tych powieści będą oznaczane odpowiednio: Sik, WC, T i $\mathrm{S}$ z podanym numerem strony.

${ }^{8}$ Por. Ewelina Zygan, „Literacka (?) rzeczywistość Trybów Magdaleny Tulli”, w: Literackie obrazy świata 3. Fikcje urealnione, red. A. Luboń, M. Karpińska (Rzeszów: Wydawnictwo Uniwersytetu Rzeszowskiego, 2019), 109-121.
} 
A gdyby zacząć grodzić historyjki drucianą siatką, ot tak, dla porządku, żeby było wiadomo, gdzie się która zaczyna, gdzie kończy i do kogo należy? Jedno jest pewne, grunt byłby wewnątrz i na zewnątrz, po naszej i po nie naszej stronie, jednakowo kamienisty. To także na nic: dla dżdżownic i kretów parkan nie jest przeszkodą, a włóczędzy przeskakują go bez trudu, kiedy nikt nie widzi. Chmury, puszczone luzem, przynajmniej odlatują tam, gdzie wiatr je pędzi, i nie wracają, czego niestety nie da się powiedzieć o pytaniach zakopanych w jałowych piaskach historyjek. Już sama myśl o ich monotonnym przesypywaniu się wywołuje znużenie [T 30].

I nieco dalej:

Historyjek nie brakuje, wszędzie ich pełno, za sprawą niepohamowanej podaży można je mieć za bezcen w dowolnych ilościach. Ale i tak nikt ich nie chce, narrator też woli omijać je z daleka. Jeśli mimo wszystko epizod taki jak ten przyciąga jego uwagę, to tylko ze względu na pewne nadprogramowe możliwości, które w sobie kryje. Jeśli dojdą do głosu, nieuchronnie odmienią bieg wszystkich kolejnych zdań, przynajmniej do końca akapitu [T 33].

Gest wyróżnienia „historyjki” jest jednocześnie położeniem akcentów na określone elementy organicznie niesamodzielnych opowieści. Składnia wyznacza bieg zdarzeń, ale przecież dzieje się to za sprawą narratorskiej świadomości aranżacji, ustalenia zależności między wskazanymi obiektami, stanami, czynnościami, które - w najlepszym razie czytelniczego wrażenia - są imitacją logiki ciągu dalszego.

Czy zatem wypowiedź narratora w prozie Tulli jest podejrzewana o potoczność? Zdecydowanie tak. W tej krytycznej adaptacji opowiadania jako czynności eksponującej potencjalność wyboru (obiektów, zależności, historyjek rozumianych jako momenty kondensacje, określone stany skupienia treści) znajduje się ważna przesłanka do myślenia o prozie autorki Trybów jako o opowieści entropicznej. Przyczyny cząstkowe właśnie, czyli aranżacje doraźne, przypadkowe, niemające swoich ciągów uzasadnień w całej narracji, lecz jedynie w pewnych momentach zgęszczenia - to podstawowe zjawiska upodabniające narrację do potoczności nie za sprawą leksyki, tylko (przede wszystkim) składni.

Entropia pojmowana jako spontaniczne rozpraszanie się energii i miara stopnia nieuporządkowania staje się tu głównym źródłem analogii. Warto jednak od razu podkreślić, że koncentrujemy się na aspektach składniowych (w szerokim sensie obejmującym semantyczne konsekwencje rozszerzonej łączliwości) i - w konsekwencji - tekstowych, czyli nie tyle ważna okazuje się figura narratora, ile konstrukcja zdań, za pomocą których tę historię (te historie) się opowiada (konstruując równocześnie obraz podmiotu mówiącego w tekście). Przyjrzyjmy się kolejnemu fragmentowi prozy:

Winna jest natura całości, to ona nie zna równowagi. Brukowany dobrymi chęciami, podpierany złamanymi nakazami sumienia, świat zawsze w końcu zaczyna się walić tu albo tam. Każda jego zapaść dla kogoś okazuje się katastrofą, po każdej stąd albo stamtąd płyną naglące wołania o ratunek. Żelazne prawa akustyki czynią je niesłyszalnymi. Trudno się wyrzec nieuwagi, sytej, zapatrzonej w siebie niechęci do szczegółów. Zbyt dokładna znajomość rzeczy zawsze narzuca jakieś powinności [S 172-173]. 
Mamy zatem układ świata, w którego obrębie zachodzą zjawiska powtarzalne, choć zarazem nieprzewidywalne. Mamy też służącą entropii personifikację, a właściwie podmiotowe równouprawnienie, ponieważ łączliwość semantyczna zdaje się u Tulli czerpać z całego bogactwa paradygmatycznego. Jest to ważny sygnał tego, że entropiczność realizuje się na poziomie składni tekstu. Kategorie nominalne nie są konwencjonalnie przypisane do grupy żywotnych czy nieżywotnych - ich sprawczość (czy raczej nieprzewidywalność) przejawia się w rozszerzonej łączliwości. Dzieje się to w obrębie relacji predykatowo-argumentowych (historyjki dochodzq do głosu, natura nie zna równowagi), jak również - przydawkowego przyporządkowania atrybutów (zapatrzona w siebie niechęć do szczegótów, zapaść świata). Podawana w ten sposób w wątpliwość elementarna kategoryzacja w obrębie zwyczajowego obrazu świata stwarza przestrzeń do pojawiania się zdarzeń emergentnych, takich więc, które - pozornie bez przyczyny - wyłaniają się ze złożonych, wieloelementowych porządków. To nie narrator (człowiek) decyduje o przebiegu zdarzeń - one się dzieją do tego stopnia niezależnie, że miarą stopnia nieuporządkowania staje się składnia administrowanej (przez chwilę, przez narratora) opowieści. Potencjalność jednak to nie kreatywność, tylko raczej niewspółmierność narzędzia opisu do bogactwa okoliczności, aporii kontekstu. Wobec tego każda ekspozycja tekstowa staje się wycinkiem, miniaturą świata, nietrwałym układem zamkniętym, w którym działają zależności językowe, ale funkcjonują one wyłącznie na prawach momentalnej metafory. Tę zaś powołuje do życia osoba opowiadająca ${ }^{9}$, która jest także funkcją tekstu i metaforą samą w sobie. Figura narratora (czy podmiotu) ma bowiem swą bytową podstawę wyłącznie w języku, choć istnieje na granicy światów, w ontologicznym rozdarciu ${ }^{10}$.

Spójrzmy na kolejny przykład - tym razem ze Snów i kamieni:

Gdy drzewo świata zapłonęło żywym ogniem i spopielałe liście spadły z jego gałęzi, z zawieruszonej pestki w niedługim czasie coś zaczęło kiełkować. Dlaczego właśnie wtedy, dlaczego w tym miejscu i dlaczego tak? Zależało to od niepowtarzalnych właściwości sezonu, od jakości gleby i od wiatrów. Krótko mówiąc, nie mogło być inaczej. Zaczęły rosnąć jednocześnie budowle publiczne i mieszkalne, wielkie, średnie i nieduże, strzeliste lub klocowate, ozdobne lub zwyczajne [Sik 7].

Konsekwentne wyzyskiwanie semantycznej łączliwości rozszerzonej jest także - co typowe dla Tulli - tworzywem konstrukcji metaforycznych. Warto jednak zaznaczyć, że obraz drzewa świata, którym rozpoczyna się mikropowieść Sny i kamienie, nie jest przez to metaforą izolowaną. Charakterystyczny potencjał entropicznej opowieści daje bowiem efekt metafory rozproszonej, przez co rozpatrujemy zjawiska semantyczne na przestrzeni tekstu, a nie lokalnie. Dekompresja metaforyki zatem jest tu efektem wywołanym przez co najmniej dwa czynniki - wskazaną już rozszerzoną łączliwość semantyczną, która motywuje redefiniowa-

\footnotetext{
${ }^{9}$ Kwestię tę - w kontekście rozważań o afektach - podjął Marek Zaleski w szkicu „Niczym mydło w grze w scrabble” (Teksty Drugie: teoria literatury, krytyka, interpretacja 6 [2013]: s. 33-47). Autor pisze: „Każdy fakt, nawet ten ze świata przyrody, jest dla nas dostępny jedynie przez czyjąś o nim opowieść. Tym samym implikuje wzory fabularyzacji, czyli wyjaśniania i umieszczania go w kontekście innych faktów. «Historyjka» przesłaniająca zdarzenie słowami steruje naszym rozumieniem świata i jego interpretacjami. A skoro nie ma czystych zdarzeń, a tylko czyjeś ich interpretacje, wszelkie nasze wypowiedzi o świecie są tylko fragmentem naszej autobiografii - jeśli tak, to zagadnienie odpowiedzialności za nasze idee i produkowane przez nas «historyjki» jawią się z nową siłą" (s. 42-43).

${ }^{10} \mathrm{Na}$ potrzeby tego tekstu pojęciem narratora oznaczamy zarówno „ja” mówiące, jak i podmiot utworu, nie wprowadzając rozróżnienia poziomów komunikacyjnych.
} 
nie elementów świata przedstawionego (w prostym ujęciu - redefiniowanie znaczeń kategorii nominalnych, ponieważ to rzeczowniki są podstawowymi wykładnikami kategoryzacji), jak również przez labilność narracyjnej perspektywy, która wyraża się niejednorodnością stylistyczną opowieści, a na innym poziomie - zmiennością narracyjnego punktu widzenia i wspominanym już ontologicznym zachwianiem podmiotu, który kreuje świat przedstawiony wraz z samym sobą, nie rezygnując przy tym z odniesień do realności pozatekstowej (jak choćby przywołania intertekstualne).

Tę drugą kwestię dookreślimy za pomocą pojęcia akomodacji stylistycznej.

\section{Artykulacja wielości}

Zanim jednak przyjrzymy się kwestii naddania jako swoistej cechy wypowiedzi literackiej ${ }^{11}$ (z perspektywy stylistycznej), przywołajmy kwestię redundancji, która myślenie o nadmiarze sytuuje w szerszym planie. Jest to tym bardziej uzasadnione, że zjawisko ma swoją teorioinformacyjną motywację, która z kolei odsyła w oczywisty sposób do entropii. Redundancja u podstaw ewokuje nadmiar - informacji, tekstu czy stylistycznej ekspozycji. Badana w odniesieniu do tekstów informacyjnych pozwala na dystansowanie się od negatywnego wartościowania, w każdym bowiem przejawie naddatku: repetycji, parafrazy, autoreferencji, zawiera się potencjał skutecznego oddziaływania, zmiany akcentów, perswazji czy manipulacji ${ }^{12}$.

W tekstach literackich redundancja ma nieco inne funkcje wynikające z założenia, że żaden nadmiar nie daje się w tym przypadku sprowadzić do obiektywizowanej informatywności. Oznacza to, że z zasady nadmiarowość jest cechą organiczną tekstów literackich jako parametr nie wprost proporcjonalny do objętości tekstu. Przykładem tego może być choćby eliptyczność jako zjawisko akcentujące potencjalność wielu rozwiązań niwelujących brak odczuwalny na poziomie tekstu. Niekompletność gramatyczna jest w tym przypadku tekstowym wykładnikiem nadmiaru, ponieważ wielość możliwości uzupełnienia nie spełnia warunku koniecznego, tylko eksponuje różnorodne (i uprawomocnione przez literackość tekstu) rozwiązania (interpolacje, eksplikacje) ${ }^{13}$.

\footnotetext{
${ }^{11}$ Cechy, dodajmy, charakteryzującej i definiującej literackość od czasów Romana Jakobsona. Na „nadmiar literatury w literaturze" wskazuje u Tulli również Agnieszka Izdebska (Izdebska, 304).

${ }^{12}$ Wnikliwej analizy sposobów rozumienia i definiowania redundancji dokonała Agnieszka Kula w pracy Redundancja w mediach. Studium pragmalingwistyczne (Poznań: Wydawnictwo Naukowe UAM, 2017). Autorka zwróciła na początku uwagę na określony paradoks: „redundancja właściwie nie zajmuje współczesnych językoznawców, [...] w bibliotecznym katalogu wokół tego pojęcia dostrzegalny jest niedobór lektur z dziedziny humanistyki, a dokładniej - panują niepodzielnie rządy specjalistów dwóch dziedzin: teorii informacji oraz kultury języka. To jeden z zasadniczych powodów, dla których nadmiar jako synonim redundancji trzyma się mocno: dla obu perspektyw jest to odniesienie wystarczające, choć z różnych powodów. Teorioinformacyjnie nadmiar to zapas, rezerwa dla zabezpieczenia sygnału (wartościowanie pozytywne), kulturalnojęzykowo - wyjście poza normę (wartościowanie negatywne)" (s. 10-11). Kwestia poruszana przez Kulę ma znaczenie podstawowe, choć wspomniane rządy są być może (w zwyczaju językowym) jednak podzielne - króluje raczej przekonanie, że redundancja to nadmiar zbędny, zbytek. O nowszych odniesieniach językoznawstwa do teorii informacji piszą także Marek Osiewicz i Krzysztof Skibski w artykule „Struktura statystyczna polskiego systemu graficznego. Analiza historyczno-porównawcza”, Poznańskie Studia Polonistyczne. Seria Językoznawcza 2 (2012): 87-116.

${ }^{13} \mathrm{~W}$ tym także sensie redundancja wpisuje się w serię paradoksów wyróżnianych w monografii A. Kuli. Przy tej okazji należy podkreślić, że książka znacznie wykracza poza kwestie nadmiarowości w mediach, co z pewnością otwiera perspektywę do tropienia redundancji w tekstach artystycznych.
} 
Redundancja w tekście literackim może też przybrać inne formy. W prozie Magdaleny Tulli objawia się przede wszystkim wielością hipotetycznych podmiotowych perspektyw, nadmiarem funkcjonalizowanych w opisie elementów języka, wreszcie - wielowątkowością narracji.

Można w tym miejscu przywołać obraz ze Skazy: szyny tramwajowe są ułożone dokoła placu (tworząc zamknięte koło), a oto któregoś dnia tramwajem przyjeżdżają ludzie. Zrazu kilkoro, potem znacznie więcej. Przybywają i - ponieważ plac jest zharmonizowany z dotychczasowym myśleniem o świecie tych, którzy zamieszkują okolice (można by stwierdzić: skrojony na miarę) - nie mają się gdzie podziać. Mamy zatem do czynienia z sytuacją nadmiaru rozumianego po prostu jako niemożność ukazania zasadności określonych zjawisk w odniesieniu do przyjętych reguł zorganizowania jakiejś całości. Nieuzasadnione jest samo pojawienie się dodatkowych obiektów, a także ich funkcja w dotychczasowym porządku.

Czy to mało każdy ma starych, miejscowych zmartwień? Nowego kłopotu nam nie potrzeba. A przecież w końcu liczyć się należy i z tym, że za przyjezdnymi, zakutanymi w palta, szaliki i czapki z nausznikami, nadciągnie obcy tutejszej atmosferze surowy klimat: zamiecie śnieżne albo trzaskający mróz. Można jeszcze tylko mieć nadzieję, że gdy przywleczone przez nich wątki zostaną od razu krótko ucięte, to przybysze posiedzą przez jakiś czas na walizkach, a potem, nie mając się o co zaczepić, znikną razem z nimi. Ot, po prostu, rozpłyną się w powietrzu, kładąc kres nieoczekiwanemu załamaniu porządku, i wcześniejszy stan rzeczy zostanie szczęśliwie przywrócony [S 66-67].

Myślenie o tego typu nadmiarze, które każe - w drodze prostych sprawdzianów funkcjonalności - uznać niedopasowanie wprowadzonych do całości elementów, odniesione do sposobu konstruowania opowieści u Tulli tylko pozornie jest niestosowne. U podstaw takiego sposobu organizowania wypowiedzi bowiem leży problem referencji oraz wynikające z tego oczekiwania minimalne.

Przyjmijmy (wyprowadzając to założenie z „późnej” myśli Wittgensteina), że sposób oceny opisu sytuacji poprzedzają i determinują wcześniejsze użycia języka ${ }^{14}$. Nie odnosimy się po prostu do kategorii gry językowej, ponieważ równie dobrze można by ją rozpatrywać w kontekście poprzedzających użyć, jak i użycia obecnego (także literackiej wypowiedzi odczytanej i interpretowanej przez odbiorcę) ${ }^{15}$. Gramatyczna (dynamiczna) stabilność języka wyłaniająca się z nieprzerwanych językowych aktywności daje konsekwencje w postaci określonych oczekiwań odbiorczych. Nie chodzi tu o formalne parametry tekstów językowych (włączające aspekt normatywny w sensie preskryptywnym), lecz o sposób rozumienia, przyjmowania wypowiedzi jako akceptowalnych lub nie. $\mathrm{W}$ takim właśnie nieizomorficznym ujęciu można badać narrację, która nie odnosi się w sensie ścisłym do rzeczywistości pozajęzykowej, tylko

\footnotetext{
${ }^{14}$ Por. Zaleski, „Niczym mydło w grze w scrabble”, s. 35. Badacz, analizując (za Deleuze’em) relacje między pojęciami esencji i poznania przez afekt („Esencje są czymś, co przekracza zarówno stan subiektywny podmiotu poznającego, jak i właściwości przedmiotu poznawanego”), dodaje: „Czy język, w którym znaczenia ustanawiają się w grze różnic, nie jest matrycą takiego poznania? Każde użycie języka partycypuje w jego systemowości, ale systemowość manifestuje się przez użycie. Jednak użycie użyciu nierówne. Zdaniem Deleuze’a to literatura jest właśnie taką manifestacją języka, w której esencje (i różnice) najbardziej intensywnie dochodzą do głosu za sprawą indywidualnego stylu".

${ }^{15}$ Por. Elżbieta Chrzanowska-Kluczewska, Language-games: pro and against (Kraków: Universitas, 2004).
} 
odsyła do określonej przestrzeni użycia języka ${ }^{16}$. Ten sposób rozważania kwestii odniesienia przywodzi na myśl (zgodnie ze sposobem myślenia obecnym w literaturze przedmiotu) semantyki nieodniesieniowe, które - w podstawowym ujęciu - wskazują na wyłanianie się znaczenia $z$ sieci kontekstualnych peryfraz, a nie z konstrukcji elementów językowych o ściśle określonych (wyznaczonych) właściwościach semantycznych ${ }^{17}$.

Powyższy passus w żadnej mierze nie ma pretensji do rozstrzygnięć w zakresie rozumienia gramatyki, akcentuje jedynie to, że w przypadku gramatyki literackiej (a z oryginalnym przykładem takiej mamy z pewnością do czynienia w prozie Tulli) potencjalność semantyczna narracji jest ściśle związana z dynamiką użycia języka, który odsyła do przestrzeni znaczenia użyć języka poprzedzających tę narrację.

Mamy tutaj zatem dwa problemy. Pierwszy dotyczy kwestii metajęzykowych i koncentruje się na odniesieniu języka wypowiedzi narratora do języka typowej (oczekiwanej) wypowiedzi osoby mówiącej o jakichś zdarzeniach. W tym sensie narrator u Tulli jest dyskursywny, a jego wypowiedź wymaga specjalnej strategii odbiorczej, która zapewni spójność tekstu w odbiorze. Drugi natomiast - związany z przytoczonym fragmentem ilustrującym redundancję - wiąże się z opisywanymi wydarzeniami, których odniesienie (uzasadnienie w logicznym, przyczynowo-skutkowym porządku tekstu) także domaga się odrębnej strategii. Bez jej zastosowania bowiem możemy w tym przypadku z nadmiarowości łatwo przejść do zarzutu nieczytelności, nieklarowności czy sprzeczności wyróżnionych w opisie zdarzeń.

Omówmy to na przykładzie Skazy. Na początek przytoczmy obszerniejszy fragment powieści.

Tymczasem tramwaj zdążył zatoczyć nowe koło i jest już w połowie następnego. Na przystanku przed gimnazjum właśnie wysiada z niego panna służąca. Niesie koszyk z włoszczyzną i kurą na rosół dla notariusza i jego rodziny. Policjant, być może, chętnie pochwyciłby ten koszyk i wniósł go na kuchenne schody, zwłaszcza gdyby był młodszy albo po cywilnemu, lecz powaga munduru i służby na to nie pozwala, więc tylko strzeli palcami w błyszczący daszek czapki. Ona, zachęcająco nadąsana, obrzuca go przeciągłym spojrzeniem, ale się nie zatrzymuje, znika w bramie pod siódmym. Nic jej to nie obchodzi, z jakiej mianowicie całości został wyrwany ten fragment dzielnicy, jakiego to wielkiego miasta ma on być częścią. Należałoby dodać, że gryf czy też orzeł na czapce policjanta jest miniaturą godła państwowego znad bramy urzędu, jednym z tych licznych drapieżników, białych, czarnych, srebrnych, dwugłowych i rozmaitych, bytujących zwyczajowo na fasadach gmachów publicznych. Ich poza oraz kształt szponów i skrzydeł zależy tylko od tego, gdzie rzecz się dzieje. Policjant, zwodzony widokiem dzwonnic i wież tkwiących gdzieś na drugim planie, ponad dachami, we mgle oddalenia, a przez to nie całkiem oczywistych, także miałby słuszne prawo wiedzieć,

\footnotetext{
${ }^{16}$ Por. Ewa Bińczyk, Obraz, który nas zniewala. Współczesne ujęcia języka wobec esencjalizmu i problemu referencji (Kraków: Universitas, 2007), 136-150); Alfred Gawroński, Dlaczego Platon wykluczył poetów z Państwa? U źródeł współczesnych badań nad językiem (Warszawa: Biblioteka Więzi, 1984), 65-152; Marta Wołos, Koncepcja „gry językowej” Wittgensteina w świetle badań współczesnego językoznawstwa (Kraków: Universitas, 2002),

${ }^{17}$ Kwestię semantyki nieodniesieniowej w kontekście filozofii Donalda Davidsona opisuje Janusz Maciaszek („Filozofia Donalda Davidsona. Podstawy semantyki”, Bibliotheca Philosophica 4 [2019]: 111-170). Por. też Ewa Bińczyk, Aleksandra Derra, „Wybrane problemy programu semantycznego Donalda Davidsona”, Przegląd Filozoficzny 2 (2006): 179-194; Davidson, 215-226.
} 
czyż nie? Lecz nigdy o to nie zapyta, zadowoliwszy się kojącym brzmieniem słowa „tutaj”. Rzecz nie dzieje się tu albo tam. Cała mieści się w sobie jak w szklanej kuli, w której jest wszystko, czego potrzeba na każdą przewidzianą okoliczność [S 21-22].

Dyskursywność narratora pojawia się niejako w efekcie niemożności jednoczesnego opisu z różnych perspektyw. Relacjonowanie wydarzeń bieżących koncentruje się na postaci wysiadającej z tramwaju (wysiada, niesie, obrzuca spojrzeniem, nie zatrzymuje się etc.), ale obejmuje też potencjalność lub następowanie ciągów dalszych (być może, chętnie pochwycitby, strzeli palcami). Na dodatek dołącza się też rozważanie szerszych uwarunkowań, detali, mających wpływ na tę sytuację (należałoby dodać) czy na perspektywę współwystępującego w tej scenie policjanta (miałby słuszne prawo wiedzieć, nigdy o to nie zapyta). Pod koniec tego akapitu opowieść wraca do relacji, jednak jest to już perspektywa zapośredniczona - narratora, którego wypowiedź implikuje (typową w prozie Tulli) formułę: „jeśli jestem policjantem”. Strategia odbioru wymaga tu zatem przyjęcia wieloaspektowości opowieści, w której relacja jest interpretacją, a zatem wypowiedź nosi znamiona peryfrazy ${ }^{18}$. Nie chodzi jednak o proste omówienie substytutywne, lecz o niearbitralność dynamicznej wypowiedzi osoby, która waha się przed pochopną kategoryzacją.

Mamy więc do czynienia z oboma wskazanymi wcześniej problemami: z nadmiarowością na poziomie gramatyki tekstu (tę kwestię omówimy za chwilę szczegółowiej) oraz wieloaspektowością opisu połączoną z wieloczynnikowością przedstawionej sceny. Nie mamy jednak pewności, że wszystkie elementy pozostają ze sobą w naturalnej relacji - sytuacja ta jest wywołana osobliwością przedstawionego miejsca: okrągły plac, dookoła jadący tramwaj, dwa przystanki, a więc maksymalizowane tu, choć już nie tylko teraz. Odniesienie do oczekiwań odbiorczych zostaje wystawione na próbę w dwójnasób. Po pierwsze dlatego, że narrator odwołuje się do różnych gramatycznych wykładników czasu w zależności od dołączanych elementów opisu zdarzeń, po drugie zaś - z powodu nieoczywistej struktury przyczynowo-skutkowej opisywanych wydarzeń.

To jednak powierzchowny wniosek. W istocie bowiem jest to wyraźna ilustracja redundancji niepojmowanej negatywnie. Nadmiarowość bowiem stanowi naturalną konsekwencję używania języka w dyskursywnej praktyce adaptowania zmiennych warunków kontekstu (podobnie rzecz się ma w języku mówionym, choć - oczywiście - towarzyszą temu zazwyczaj odmienne wykładniki spójnościowe).

W tym miejscu warto przywołać koncepcję, która co prawda wyrosła na podstawie strukturalistycznej refleksji językoznawczej, ale pozostaje niezmiennie inspirująca i dobrze koresponduje z prowadzonymi tu rozważaniami o nadmiarze. Pojęcie akomodacji stylistycznej zostało opisane przez Teresę Skubalankę w odniesieniu do dwu zasadniczych perspektyw: adaptacji gramatycznej umożliwiającej elementarną zrozumiałość wypowiedzi i - co dla nas bardzo

\footnotetext{
${ }^{18} \mathrm{Na}$ ten aspekt peryfrazy zwrócił uwagę Michał Głowiński w odniesieniu (przede wszystkim) do tekstów propagandowych. Z pewnością jednak wyraźna interpretacyjna moc peryfrazy jest zjawiskiem istotnym także z punktu widzenia komunikacji literackiej. Zdecydowanie też w tym ujęciu należy rozpatrywać pojęcie stylu peryfrastycznego, które jednak trzeba by poddać gruntowniejszej analizie (Nowomowa po polsku [Warszawa: Wydawnictwo Open, 1990], 31-37).
} 
istotne - adaptacji naddanej ${ }^{19}$. Pierwsza $z$ nich (zbieżna ze sposobem myślenia o adaptacji składniowej) odnosi się do ujęcia elementów języka w reguły wypowiedzi, której gramatyczny porządek (syntagmatyczny przede wszystkim) gwarantuje podstawową zrozumiałość tekstu. Badaczka mówi w tym przypadku o stylistycznej akomodacji prostej i wskazuje, że - jako transmisja realizowana przede wszystkim za pomocą selekcji, derywacji, linearyzacji, komponowania tekstu i dążenia do jego spójności - jest ona obligatoryjna. Bez tego nie może być mowy o tekście, a więc także - o progowych warunkach komunikacji. Z kolei stylistyczna akomodacja naddana ma status fakultatywnej i przejawia się w bardziej zaawansowanych procesach - między innymi w intensyfikacji, redukcji, kontaminacji, substytucji. Ten rodzaj adaptacji nosi już znamiona przetworzenia, a więc - w odniesieniu do naszych powyższych rozważań - tworzenia napięcia pomiędzy oczekiwaną wypowiedzią potencjalną a jej sytuacyjną realizacją.

Przypomnijmy też, że wymienione przez badaczkę procesy nie oznaczają, iż redundancja możliwa jest tylko w efekcie intensyfikacji czy kontaminacji. Jeśli bowiem przyjąć, że (jak powiedzieliśmy wcześniej) eliptyczność ma również potencjał nadmiaru, to wszystkie przejawy akomodacji naddanej niewątpliwie by się w tym mieściły. Daje to więc możliwość rozpatrywania nadmiarowości w ścisłej relacji z entropią, jak również z szeroko rozumianą peryfrastycznością - oba pojęcia bowiem odnoszą się w tej perspektywie do języka w użyciu, a także do semantyki o niereifikującym odniesieniu.

Rozważmy jeszcze jedno zjawisko języka tekstów Magdaleny Tulli, które to dobrze koresponduje z poczynionymi tu ustaleniami. Będzie nam dzięki temu łatwiej zbliżyć się do istotnych - naszym zdaniem - konkluzji ogólniejszej natury.

\section{Pozory asamblażu}

Prowadzone dotąd rozważania dotyczące nadmiarowości i entropiczności jako cech wczesnych powieści Magdaleny Tulli nie mają ambicji wpisywania się w dynamikę wypowiedzi krytycznych dotyczących tej prozy. W ich świetle bowiem osobliwości języka tych tekstów nie zawsze zasługiwały na wyrazy uznania. Wychodzimy z założenia, że wskazywane tu zjawiska językowe dowodzą oryginalności stylu tych tekstów, a jednocześnie pozwalają zastanowić się nad fenomenem poetyckości oryginalnych narracji, która to wynika z określonych możliwości języka, stając się asumptem do coraz to nowego badania wypowiedzi artystycznych. W takim ujęciu zatem proza ta zyskuje niewątpliwy walor analitycznego egzemplum za sprawą swoich wyraźnych cech swoistych.

Na tę okoliczność chcielibyśmy zwrócić jeszcze uwagę na szczegół charakterystyczny dla wszystkich czterech wczesnych powieści Tulli - osobliwy zabieg składniowy stosowany w narracji, który w efekcie pozwala imitować wielogłos, dookreślając osobliwość opowieści.

Przyjrzyjmy się czterem przykładom.

${ }^{19}$ Por. Skubalanka, 13-53. 


\begin{abstract}
Kto zapragnie opuścić Ściegi, może się chwycić jednego z dwu sposobów. Jeśli jest przyjezdnym - na przykład akwizytorem własnych zalet, zmuszonym ubiegać się o przyszłość rynku, kolekcjonerem przeżyć, nauczonym przez życie pokory - powinien o brzasku bez namysłu wznieść się w górę w gondoli zawieszonej pod balonem sterowca. [...] Jeśli ten ktoś przed rozpoczęciem przygotowań do podróży zechce przejrzeć rozkłady jazdy pociągów albo prospekty linii oceanicznych, szybko się przekona, że pragnienie wyjazdu nie ma się nijak do kalendarza i do zegara [WC 106].
\end{abstract}

Jeśli świat jest maszyną, to oddzielanie rzeczy od przeciwrzeczy musi się zacząć od uszczelnienia obudowy. Od wykonania sklepienia, które oprze się na twardym gruncie. Za jego sprawą rozstępują się wody górne i dolne i odtąd wiadomo, gdzie góra, a gdzie dół, co jest porządkiem i stałością, a co chaosem i zmianą. I wtedy dopiero można odróżnić dzień od nocy [SiK 18-19].

Teraz winda ruszy w dół, a razem z nią owo zdanie, w którym się pojawiła, i następne, i jeszcze następne. Gdyby tych kilka zdań związać razem kawałkiem porządnego sznura, zawiesić na bloku i opuścić o ileś tam kondygnacji niżej, to z punktu widzenia narratora skutek byłby ten sam [T 51].

Lecz jeśli jestem którymś z lokatorów patrzących zza firanki, rozumiem, że kłopoty nie zaczynają się od dzieci z sierocińca ani się na nich nie kończą. Już sama obecność przyjezdnych żyjących wprost na bruku jest dla mnie skandalem. Trudno spokojnie patrzeć, jak urządzają się na walizkach, jak każdy z nich mebluje skrawek placu własnymi tobołami [S 118].

Nazwijmy ów zabieg efektem składni aranżującej - czyli sposobem budowania wypowiedzi narratora za pomocą konstrukcji składniowych eksponujących warunek, przypuszczenie czy prawdopodobieństwo, ale w specjalnej funkcji metaforyzującej. W przytoczonych przykładach bowiem koncentrują się dwie właściwości: pierwsza dotyczy pozoru alternatywnej opowieści, druga - przebiegu wydarzeń. W obu przypadkach pojawia się efekt zaaranżowania dotychczasowej opowieści z częstym przewartościowaniem (jeśli jest przyjezdnym, jeśli jestem którymś z lokatorów, jeśli świat jest maszyna) lub sugestią podania jej w wątpliwość (gdyby tych kilka zdań związać razem). Pojawiająca się tu składniowa aranżacja jest gestem podwójnie (czy nawet wielokrotnie) znaczącym, można w niej bowiem odnaleźć wyraźne sygnały intertekstualne, jak choćby nawiązanie do powieści Italo Calvino Jeśli zimowa nocq podróżny, stanowiącej zbiór alternatywnych opowieści spojonych postaciami Czytelnika i Czytelniczki.

Przyjęte w narracji warunki mają osobliwą - być może silniej aranżującą -konsekwencję. Dzięki funkcjonalizacji (a więc prawdopodobieństwu zaistnienia) warunkowej opowieści implikowana jest dyspozycja ukazywania zdarzeń z różnych perspektyw, ale - w pewnym sensie - jednocześnie (lub równoważnie). Powstaje przy tym sugestia, że przy innych założeniach początkowych osiągnięty zostałby odmienny efekt zdarzenia. Jeśli tak, to narracja taka stwarza pozory asamblażu rozumianego jako aranżowanie świata przedstawionego z pozornie samodzielnych fragmentów (alternatywnych, potencjalnych wypowiedzi, zdarzeń, punktów widzenia), które stają się czynnikami jednej opowieści. Wystawia to na próbę linearność przedstawiania „historyjki”, jednak uruchamia całkiem nową kontekstua- 
lizację, podobną do tej, która konstytuuje metaforę. A może raczej - katachrezę inopijną ${ }^{20}$. Jest to więc - także w tym sensie - opowieść nadmiarowa. Na płaszczyźnie narracyjnej przekłada się ona na narrację wielowersyjną, a zatem taką, która odsłania fikcyjną, iluzoryczną naturę podmiotu mówiącego, tracącego swą moc sprawczą jako nadawca wypowiedzi, stającego się zatem nie przyczyną, lecz funkcją tekstu. Na poziomie ontologicznym opowieść nadmiarowa powoduje zachwianie wyrazistego rozgraniczenia pomiędzy fikcją a rzeczywistością pozajęzykową, zachwianie charakterystyczne dla prozy rezygnującej z dominującej roli fabuły.

Warto wspomnieć zatem o jeszcze jednej, istotnej konsekwencji opisanego sposobu konstruowania opowieści, czyli o pozycji podmiotu, tracącego - jak wspomnieliśmy powyżej - ontologiczną spójność, a zatem także wpisującego się w szczególne wymagania wobec odbiorcy. Mamy w prozie Tulli do czynienia z kategorią „ja sylleptycznego”. Pojęcie to, wprowadzone do literaturoznawstwa polskiego przez Ryszarda Nycza, oznacza „ja” rozwarstwione, antynomiczne, objawiające się równocześnie jako podmiot autorski i fikcyjny nadawca tekstu. To wewnętrzne rozwarstwienie objawia się na powierzchni tekstu, gdzie pojawia się nowy

typ podmiotowej tożsamości. Dawniejszy, z założenia hierarchiczny i wertykalny, oparty na opozycji powierzchni i głębi, wyparty zostaje przez model horyzontalny, interakcyjny i interferencyjny, w którym „ja” rzeczywiste i „ja” literackie wzajemnie na siebie oddziałują i wymieniają się własnościami; w którym podmiot przystaje na własną fragmentaryczność [...] oraz intersubiektywną i „sztuczną" naturę własnej tożsamości $[\ldots]^{21}$.

Takie zwielokrotnione istnienie opowiadającego jest także funkcją literackiej składni nadmiaru.

\section{Toczenie rzeczy - kompozycja}

Linearność opowieści jest zasadniczo zharmonizowana z oczekiwaniami czytelniczymi. Narracja ma swoje składniowe oczywistości, które - nawet jeśli zmącone - stwarzają podstawy rekonstrukcji do form spodziewanych, typowych, akceptowalnych. Prawem metafory jest odstępstwo od tych oczekiwań, a jednocześnie podsyca ono zasadność wypatrywania ciągłości i następstwa. Właśnie z tymi parametrami dyskutuje wczesna proza Magdaleny Tulli. Rzeczy toczą się tu dlatego, że narrator ma umiejętność operowania nadmiarem, który koresponduje ze sposobem myślenia o języku w użyciu, niereifikującym, nieodnoszącym się w sposób stabilny do określonych całości semantycznych. Język narracji relatywizuje wystarczalność typowego przekazu za pomocą redundancji. Tę zaś można opisywać z perspektywy stylistycznej - na przykład z użyciem pojęcia stylistycznej akomodacji naddanej (badając wszelkie przejawy nietypowego przetworzenia na poziomie składni tekstu), lub w odniesieniu do semantyki, której elementem funkcjonalnym staje się szeroko rozumiana peryfraza. Na tym tle proza

\footnotetext{
${ }^{20}$ Por. Teresa Dobrzyńska, Mówiq̨c przenośnie... Studia o metaforze (Warszawa: Wydawnictwo IBL, 1994).

${ }^{21}$ Ryszard Nycz, „Tropy «ja»: koncepcje podmiotowości w literaturze polskiej ostatniego stulecia”, Teksty Drugie: teoria literatury, krytyka, interpretacja 2 (1994): 24.
} 
Tulli okazuje się zdecydowanie nieprzeciętna, a odbiorczy apetyt poznawczy powinien w tym przypadku konfrontować się ze stopniem skonwencjonalizowania języka literatury. Być może bowiem kompozycja proponowana przez autorkę Snów i kamieni maksymalizuje obrazowość prowokowaną przez język w użyciu, wpisując się (ironicznie?) w schemat komunikacyjny wytrącający się dzięki powtarzalności oczekiwań czytelniczych.

\section{Bibliografia}

Bińczyk, Ewa, Aleksandra Derra. „Wybrane problemy programu semantycznego Donalda Davidsona". Przeglad Filozoficzny 2 (2006), 179-194.

Bińczyk, Ewa. Obraz, który nas zniewala. Wspótczesne ujęcia języka wobec esencjalizmu i problemu referencji. Kraków: Universitas, 2007.

Chrzanowska-Kluczewska, Elżbieta. Languagegames: pro and against. Kraków: Universitas, 2004.

Czapliński, Przemysław. „Wobec literackości (2): Metafikcja i nieepicki model prozy”. W tegoż: Ślady przełomu. O prozie polskiej 1976-1996, 139-164. Kraków: Wydawnictwo Literackie, 1997.

Davidson, Donald. Inquires into Truth and Interpretation. Oxford University Press, 1991.

Dobrzyńska, Teresa. Mówiąc przenośnie... Studia o metaforze. Warszawa: Wydawnictwo IBL, 1994.

Dutka, Elżbieta. „Historyjki czy historie? Parabole czy alegorie?: o prozie Magdaleny Tulli". W: Skład osobowy: szkice o prozaikach wspótczesnych. Cz. 1. Zredagowali Agnieszka Nęcka, Dariusz Nowacki i Jolanta Pasterska, 525-550. Katowice, Wydawnictwo Uniwersytetu Śląskiego, 2014.

Gawroński, Alfred. Dlaczego Platon wykluczyt poetów z Państwa? U źródeł współczesnych badań nad językiem. Warszawa: Biblioteka „Więzi”, 1984.

Głowiński, Michał. Nowomowa po polsku. Warszawa: Wydawnictwo Open, 1990.

Ingarden, Roman. „Z teorii dzieła literackiego”. W: Problemy teorii literatury. Seria 1. Zredagował Henryk Markiewicz. Wrocław: Ossolineum, 1987.
Izdebska, Agnieszka. „Proza Magdaleny Tulli - w kręgu wieloznacznej referencji”. W: Inna literatura? Dwudziestolecie 1989-2009. Zredagowali Zbigniew Andres, Janusz Pasterski, t. 1, 303-322. Rzeszów: Wydawnictwo Uniwersytetu Rzeszowskiego, 2010.

Kula, Agnieszka. Redundancja w mediach. Studium pragmalingwistyczne. Poznań: Wydawnictwo Naukowe UAM, 2017.

Maciaszek, Janusz. „Filozofia Donalda Davidsona. Podstawy semantyki”. Bibliotheca Philosophica 4 (2019): 111-170.

Mizerkiewicz, Tomasz. „Dezautomatyzacja skojarzeń kulturowych i wolność literatury - Sny i kamienie Magdaleny Tulli”. W tegoż: Stylizacje mityczne w prozie polskiej po 1968 roku. Poznań: Wydawnictwo „Poznańskie Studia Polonistyczne”, 2001.

Morawiec, Arkadiusz. „Sny i kamienie Magdaleny Tulli - płaszczyzny odczytań”, W: Literatura polska 1990-2000. Zredagował Tomasz Cieślak, Krystyna Pietrych, t. 2, 309-326. Kraków: Zielona Sowa, 2002.

Nycz, Ryszard. „Tropy «ja»: koncepcje podmiotowości w literaturze polskiej ostatniego stulecia. Teksty Drugie 2 (1994): 7-27.

Osiewicz, Marek, Krzysztof Skibski. „Struktura statystyczna polskiego systemu graficznego. Analiza historyczno-porównawcza”. Poznańskie Studia Polonistyczne. Seria Językoznawcza 2 (2012): 87-116.

Saloni, Zygmunt i Marek Świdziński. Składnia wspótczesnego języka polskiego. Warszawa: Wydawnictwo Naukowe PWN, 2007.

Skubalanka, Teresa. Podstawy analizy stylistycznej. Rozważania o metodzie”. Lublin: Wydawnictwo UMCS, 2001. 
Sławkowa, Ewa. „Sny i kamienie - traktat o języku: Magdaleny Tulli ćwiczenia z semantyki”. W tejże: Tekst literacki $w$ kręgu językoznawstwa, t. 1, 15-38. Katowice: Wydawnictwo Gnome, 2012.

Wiegandt, Ewa. „Postmodernistyczne alegorie Magdaleny Tulli”. W: Nowe dwudziestolecie. Szkice o wartościach i poetykach prozy i poezji lat 1989-2009. Zredagował Piotr Śliwiński. Poznań: Wydawnictwo WBPiCAK, 2011.

Wołos, Marta. Koncepcja „gry językowej” Wittgensteina $w$ świetle badań współczesnego językoznawstwa. Kraków: Universitas, 2002.

Zaleski, Marek. „Niczym mydło w grze w scrabble”. Teksty Drugie 6 (2013): 33-47.

- - -. „Za plecami narratora. Rozmowa z Magdaleną Tulli”. Res Publica Nowa 5-6 (1999): 79.

Zieniewicz, Andrzej. „Przedmiot (w) opowieści. Relacja jako stwarzanie wydarzeń w prozie współczesnej (na przykładzie powieści Magdaleny Tulli)". W: Narracje po końcu (wielkich) narracji. Kolekcje, obiekty, symulakra..., red. H. Gosk, A. Zieniewicz. Warszawa: Dom Wydawniczy Elipsa, 2007.

Ziomek, Jerzy. „Fikcyjne pole odniesienia a problem quasi-sądów”. W: Wypowiedź literacka a wypowiedź filozoficzna. Zredagowali Michał Głowiński, Janusz Sławiński. Wrocław: Ossolineum, 1982.

Zygan, Ewelina. „Literacka (?) rzeczywistość Trybów Magdaleny Tulli”. W: Literackie obrazy świata 3. Fikcje urealnione. Zredagowali Arkadiusz Luboń, Monika Karpińska, 109121. Rzeszów: Wydawnictwo Uniwersytetu Rzeszowskiego, 2019. 


\title{
SŁOWA KLUCZOWE:
}

\section{akomodacja stylistyczna}

GRAMATYKA LITERACKA

\author{
redundancja
}

\begin{abstract}
AbSTRAKT:
Artykuł dotyczy specyfiki języka wczesnych utworów prozatorskich Magdaleny Tulli. Zjawiska z obszaru gramatyki literackiej - specyficznego operowania nadmiarem w narracji, osobliwym typem składni aranżującej, a także twórczym wykorzystaniem potoczności - pozwalają przyjrzeć się tej prozie jako opowieści entropicznej. Przede wszystkim ze względu na charakterystyczne rozproszenie energii narracyjnej, jak również kontrastujące z czytelniczymi oczekiwaniami nieuporządkowanie. Dzięki przytoczonym przykładom i odniesieniom do wybranych koncepcji badawczych z obszaru językoznawstwa uruchomić można kolejną perspektywę namysłu nad cechami tekstów autorki „Skazy”, a dzięki temu - zadać nowe pytania o wyjątkowość opowieści zawartych w tej oryginalnie poetyckiej prozie.
\end{abstract}


n a r r a cja

\section{POTOCZNOŚĆ}

PERYFRAZA

\section{NOTA O AUTORACH:}

Bogumiła Kaniewska (1964) - literaturoznawczyni, polonistka, tłumaczka, profesor nauk humanistycznych z Uniwersytetu im. Adama Mickiewicza w Poznaniu. Specjalizuje się w historii literatury, literaturze współczesnej i teorii literatury. Autorka prac poświęconych polskiej prozie współczesnej: Narracja pierwszoosobowa w polskiej prozie wspótczesnej, Śladami Tristrama Shandy i Opowiedziane. O prozie Wiesława Myśliwskiego oraz książek popularnonaukowych, współautorka podręczników akademickich i szkolnych. Uprawia krytykę literacką (m.in. na łamach „Nowych Książek”), jest tłumaczką prozy anglojęzycznej, głównie literatury dla dzieci, którą zajmuje się także naukowo.

Krzysztof Skibski (1977) - językoznawca, polonista, dr hab.; pracuje na Wydziale Filologii Polskiej i Klasycznej Uniwersytetu im. Adama Mickiewicza w Poznaniu; zajmuje się badaniem języka literackiego (zwłaszcza w poezji współczesnej); interesuje się również metodologicznymi problemami lingwistyki, potocznością, semantyką i frazeologią; prowadzi zajęcia z zakresu językoznawstwa współczesnego i kulturowego czytania literatury; publikuje m.in. w czasopismach: „Język Polski”, „LingVaria”, „Przestrzenie Teorii”, „Forum Poetyki”; jest autorem monografii Antropologia wierszem. Język poetycki Ewy Lipskiej (2008), Poezja jako iteratura. Relacje między elementami języka poetyckiego w wierszu wolnym (2017) oraz Literackie gramatyki ciagtości i nadmiaru. Próba filologiczna (z Jerzym Borowczykiem; 2021). 